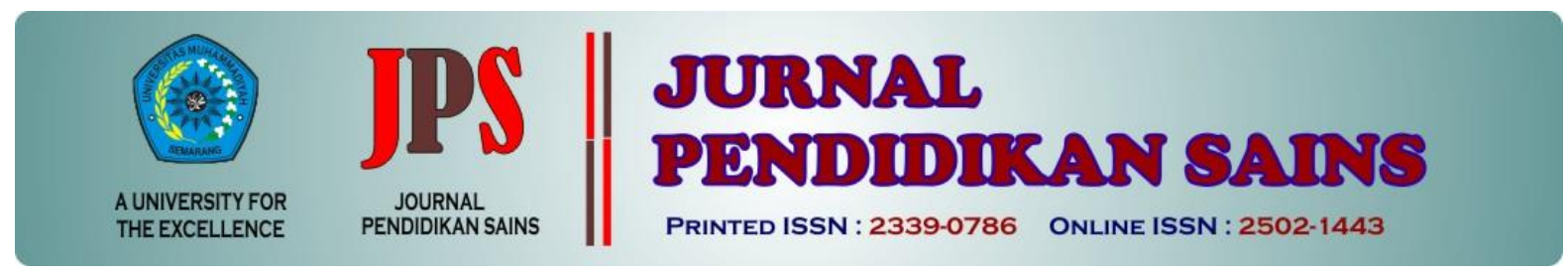

http://jurnal.unimus.ac.id/index.php/JPKIMIA

\title{
PENERAPAN MODEL PROJECT BASED LEARNING DENGAN PENDEKATAN SAINTIFIK UNTUK MENINGKATKAN HASIL BELAJAR ANALISIS GRAVIMETRI
}

\author{
Oleh: \\ Indayatmi \\ SMK Negeri 2 Depok Sleman Yogyakarta
}

\begin{tabular}{ll}
\hline \multicolumn{2}{l}{ Article history } \\
\hline Submission & $: 2019-08-07$ \\
Revised & $: 2020-02-11$ \\
Accepted & $: 2020-03-10$
\end{tabular}

Keyword:

Kata kunci: project based learning, analisis gravimetri, hasil belajar.

\section{Abstract}

This research aims to determine the application of the project based learning model with a scientific approach to improve the learning outcomes of gravimetric analysis in students class XI chemical analysis of SMK Negeri 2 Depok year 2018/2019. The research conducted consisted of 4 stages, pre cycle, cycle 1 , cycle 2 , and cycle 3 . Data collection was done through observation, evaluation of learning outcomes, assessment of project based learning processes, and documentation. The results showed that project based learning can improve the learning outcomes of gravimetric analysis on students of class XI chemistry analysis, namely the average learning outcomes on the cycle of 69 , cycle 1 at 81 , cycle 2 at 85 , cycle 3 by 87 . Use of project based learning can increase the number of students who achieve the minimum scor criteria that is in the pre cycle of 10 students, cycle 1 of 27 students, cycle 2 of 29 students, and cycle 3 of 30 students. The conclusion of this research is the application of the project based learning model with a scientific approach to improve the learning outcomes of gravimetric analysis on class XI students of chemical analysis of SMK Negeri 2 depok year 2018/2019.

\section{Pendahuluan}

Pergeseran paradigma pembelajaran dalam dunia pendidikan di abad 21 menurut Shoimin (2014) yaitu dari teacher centered bergeser menjadi student active learning. Menjadi salah satu alternatif untuk mengurangi pembelajaran teacher centered, pendidik tidak hanya mengandalkan buku pegangan mengajar, tetapi harus dilengkapi dengan model pembelajaran yang tepat. Kurangnya pendidik menggunakan model pembelajaran lain dikarenakan anggapan bahwa: belum terbiasa, perlu persiapan khusus, khawatir tidak berhasil, takut suasana belajar menjadi gaduh, tidak ada niat merubah, kebiasaan menikmati bicara, dengan anggapan yang demikian maka kemampuan mengajar pendidik berada pada taraf sedang.

Metode mengajar guru lazim menggunakan metode ekspositori, yaitu metode yang kurang berpihak pada siswa-siswa yang memiliki *Corresponding Author

Nama : Indayatmi

Lembaga : SMK Negeri 2 Depok Sleman Yogyakarta

Email : ndayatmi@ymail.com kemampuan di bawah rata-rata, sebagaimana yang disebutkan oleh Sanjaya $(2010 ; 191)$ metode ekspositori memiliki beberapa kelemahan antara lain; (1) Metode pembelajaran ini hanya dapat dilakukan terhadap siswa yang memiliki kemampuan mendengar dan menyimak dengan baik; (2) Metode ini tidak mungkin dapat melayani perbedaan setiap individu, baik perbedaan kemampuan, perbedaan pengetahuan, minat, dan bakat, serta perbedaan gaya belajar; (3) Metode ini sulit mengembangkan kemampuan siswa dalam hal kemampuan sosialisasi, hubungan interpersonal, serta kemampuan berpikir kritis; (4) Keberhasilan metode ekspositori sangat tergantung kepada apa yang dimiliki guru; (5) Gaya komunikasi pada metode ekspositori dominan satu arah (onewaycomunication).

Pendekatan saintifik (scientific approuch), adalah pendekatan yang digunakan dalam Kurikulum 2013. Pada pelaksanaan pembelajaran menjadi bahan pembahasan yang menarik 
perhatian para pendidik akhir-akhir ini yang merupakan elemen perubahan Kurikulum 2013. Kemendikbud (2014:35) pada implementasi Kurikulum 2013 menyebutkan bahwa proses pembelajaran dapat dipadankan dengan suatu proses ilmiah, karena itu Kurikulum 2013 mengamanatkan esensi pendekatan ilmiah atau pendekatan saintifik dalam pembelajaran. Pendekatan ilmiah atau pendekatan saintifik diyakini sebagai titian emas perkembangan dan pengembangan sikap, ketrampilan, dan pengetahuan siswa.

Untuk menerapkan pendekatan saintifik pada setiap proses pembelajaran dibutuhkan suatu model pembelajaran yang sesuai dengan karakteristik pendekatan ilmiah. Penggunaan model pembelajaran yang tepat dapat mendorong tumbuhnya rasa senang siswa terhadap pembelajaran, menumbuhkan dan meningkatkan motivasi dalam mengerjakan tugas atau menyelesaikan suatu masalah, dan memberikan kemudahan bagi siswa untuk memahami pelajaran sehingga memungkinkan mereka mencapai hasil belajar yang baik, selanjutnya dikemudian hari dapat terbentuk pola berpikir dan bertindak ilmiah yang menjadi suatu kebiasaan.

Elemen-elemen perubahan pada proses pembelajaran merupakan satu diantara elemenelemen perubahan pada Kurikulum 2013 (Kemendikbud, 2014) yaitu mencakup; (a) berorientasi pada karakteristik kompetensi 1) sikap, 2) keterampilan, 3) pengetahuan; (b) menggunakan pendekatan saintifik, karakteristik kompetensi sesuai jenjang harus mencakup kompetensi dalam ranah sikap, pengetahuan dan keterampilan; (c). mengutamakan Discovery Learning, Project Based Learning dan Problem Based Learning.

Karakteristik Pembelajaran Berbasis Proyek yang diterapkan di SMK menurut Waras Kamdi (2010) membentuk tiga konfigurasi model Pembelajaran Berbasis Proyek yang menampakkan graduasi dari yang sederhana ke yang kompleks dan ideal. Konfigurasi pertama, model Pembelajaran Berbasis Proyek yang menempatkan kerja proyek sebagai wahana pengembangan keterampilan teknikal, dan dominasi peran guru dalam proses penyelesaian kerja proyek sangat besar. Konfigurasi kedua, model Pembelajaran Berbasis Proyek yang menempatkan kerja proyek sebagai wahana mendekatkan belajar teori dan praktik, kontekstual, tetapi kontrol guru dalam proses penyelesaian proyek masih cukup tinggi. Konfigurasi ketiga, model Pembelajaran Berbasis Proyek yang menempatkan kerja proyek sebagai wahana pengintegrasian belajar teori-praktik, belajar pemecahan masalah kontekstual, kolaboratif, dan pemberian otonomi yang besar kepada siswa dalam pengambilan keputusan penyelesaian kerja proyek. Konfigurasi yang ketiga inilah yang ideal sebagai model Pembelajaran Berbasis Proyek, kecakapan siswa menerapkan pengetahuan akademik (teoretik) ke dalam praktik, mengungkapkan ide secara jelas, menciptakan produk yang berkualitas (bernilai), dan mengonstruksi tugas secara jelas menduduki peringkat yang paling tinggi, dalam arti semua konfigurasi model Pembelajaran Berbasis Proyek menetapkan keterampilan-keterampilan tersebut secara sadar menjadi tujuan pembelajaran. peringkat berikutnya adalah siswa dapat merencanakan produk, mengkalkulasi teknis, bahan dan biaya lainnya, dan melakukan proses produksi, serta membuat perencanaan secara efektif.

Knoll (2002) menyatakan bahwa pembelajaran Berbasis Proyek potensial berhasil memperbaiki praktik pembelajaran pada pendidikan teknologi, sehingga dimensi-dimensi kecakapan siswa academic skills, occupational skills, dan employability skills dapat berkembang secara optimal. Sedangkan menurut Thomas (2000) Potensi keefektifan belajar berbasis proyek ini didukung oleh temuan-temuan penelitian belajar kola boratif yang terbukti dapat meningkatkan pencapaian prestasi akademik, berpikir tingkat tinggi dan kecakapan berpikir kritis yang lebih baik, kemampuan memandang situasi dari perspektif lain yang lebih baik, pemahaman yang mendalam terhadap bahan belajar lebih bersikap positif terhadap bidang studi, hubungan yang lebih positif dan suportif dengan kawan sejawat, dan meningkatkan motivasi belajar

Langkah langkah pembelajaran Project Based Learning Menurut Kosasih (2014:98) dilaksanakan dengan enam langkah yaitu; penentuan proyek, perancangan langkah-langkah penyelesaian, penyusunan jadwal pelaksanaan proyek, penyelesaian proyek dengan fasilitas dan monitoring guru, penyampaian hasil kegiatan dan presentasi, evaluasi proses dan hasil proyek. Pembelajaran Project Based Learning akan dapat meningkatkan keterampilan psikomotorik serta hasil belajar siswa pada mata diklat produktif, jika model pembelajaran yang digunakan tepat serta tersedianya fasilitas yang mendukung dalam kegiatan belajar mengajar. Sedangkan dalam diri siswa yang juga dapat mempengaruhi hasil belajar, yaitu kemampuan siswa menguasai fasilitas belajar diantaranya penguasaan cash register dan display produk yang sesuai dengan SOP, siswa bekerja dengan cepat, tepat dan efisien serta bagaimana siswa membuat produk yang kreatif dan inovatif. 
Impelementasi kurikulum 2013 dalam pembelajaran dengan pendekatan saintifik menurut Hosnan (2014) merupakan proses pembelajaran yang dirancang sedemikian rupa supaya siswa secara aktif mengkonstruksi konsep, hukum, prinsip melalui tahapan mengamati, merumuskan masalah, merumuskan hipotesis, mengumpulkan data, menganalisis data, menarik kesimpulan, mengkomunikasikan hasil konsep. Pendekatan saintifik bertujuan untuk memberikan pemahaman kepada siswa dalam memahami materi menggunakan pendekatan ilmiah, informasi bisa berasal dari mana saja, tidak harus dari informasi searah dari guru. Kondisi pembelajaran diarahkan untuk mencari informasi dari observasi, bukan dari diberi tahu oleh guru.

Penerapan pendekatan saintifik dalam pembelajaran melibatkan keterampilan proses seperti mengamati, mengklasifikasi, mengukur, meramalkan, menjelaskan, dan menyimpulkan. Dalam melaksanakan proses tersebut, bantuan guru diperlukan tetapi bantuan guru harus semakin berkurang dengan semakin bertambah dewasanya siswa atau semakin tinggi kelas siwa (Hosnan, 2014)

Pendidik harus mempelajari tentang model pembelajaran yang akan digunakan. Pendidik yang menguasai beberapa model pembelajaran maka akan mudah pelaksanaan pembelajaran di kelas sehingga tujuan pembelajaran dapat tercapai dan tuntas sesuai yang diharapkan (Trianto, 2011).

Tingkat kelayakan suatu model pembelajaran pada aspek validitas menurut Huda (2013) dibutuhkan ahli dan praktisi untuk memvalidasi model pembelajaran yang dikembangkan. Sedangkan untuk aspek kepraktisan dan efektifitas diperlukan suatu perangkat pembelajaran untuk melaksanakan model pembelajaran yang dikembangkan.

Pengertian belajar menurut Sanjaya (2010) adalah perubahan perilaku sebagai akibat pengalaman dan latihan. Belajar tidak sekedar mengumpulkan pengetahuan. Belajar merupakan proses mental yang terjadi pada diri seseorang, sehingga menyebabkan munculnya perubahan perilaku. Aktivitas mental itu terjadi karena adanya interaksi dengan lingkungan yang disadari. Proses belajar pada hakikatnya merupakan kegiatan mental yang tidak dapat dilihat, artinya proses perubahan yang terjadi dalam diri seseorang yang belajar tidak dapat dilihat. Yang bisa dilihat adalah gejala-gejala perubahan perilaku. Belajar pada dasarnya menyangkut perubahan tingkah laku seseorang yang bersifat permanen disebabkan oleh interaksi dengan lingkungannya. Secara sederhana belajar dapat diartikan sebagai aktivitas mental atau psikis yang berlangsung secara timbal balik antara siswa dengan sumber-sumber belajar, baik sumber belajar yang didesain maupun yang dimanfaatkan. Perbuatan dan hasil belajar dapat dimanifestasikan dalam wujud: pertambahan materi pengetahuan yang berupa fakta, prinsip, hukum, teori, sistem nilai, penguasaan pola-pola perilaku kognitif, perilaku afektif, perilaku psikomotorik, perubahan dalam sifat-sifat kepribadian, misalnya kritis, tekun, teliti, kreatif, dan terbuka. Belajar menurut Aqib (2013) tidak hanya sekedar menghafal. Siswa harus mengkonstruksikan pengetahuan. Siswa belajar dari mengalami, mencatat sendiri pola-pola bermakna dari pengetahuan pendidik dan tidak hanya diberi saja oleh pendidik.

Berdasarkan dari beberapa pendapat di atas, dapat dikatakan bahwa belajar adalah suatu suatu aktivitas siswa dalam interaksi edukasi dengan langkah-langkah tertentu yang terencana, tersusun dan terarah sehingga menghasilkan perubahan tingkah laku yang relatif permanen dan berbekas yang meliputi pengetahuan, keterampilan, dan nilai sikap sebagai akibat interaksi dengan lingkungan. Belajar dalam penelitian ini merupakan segala usaha dan aktivitas siswa yang diarahkan oleh pendidik agar siswa mampu menguasai kompetensi tertentu.

Penilaian hasil pembelajaran menurut Rusman (2014) untuk mengukur tingkat pencapaian kompetensi peserta didik, serta digunakan sebagai bahan penyusunan laporan kemajuan hasil belajar dan memperbaiki proses pembelajaran. Penilaian digunakan secara konsisten, sistematis, dan terprogram dengan menggunakan tes dan nontes dalam bentuk tes tertulis, tes lisan, pengamatan kerja, pengamatan sikap, penilaian tugas, penilaian proyek.

Penilaian hasil belajar menggunakan berbagai teknik penilaian berupa tes, observasi, penugasan perseorangan atau kelompok, bentuk lain yang sesuai dengan karakteristik kompetensi dan tingkat perkembangan peserta didik. Tes yang dilakukan dapat berupa tes tertulis, tes lisan, tes praktik. Teknik observasi atau pengamatan dilakukan selama pembelajaran berlangsung. Instrumen penilaian hasil belajar yang digunakan harus memenuhi persyaratan: merepresentasikan kompetensi yang dinilai, memenuhi persyaratan teknis sesuai dengan bentuk instrumen yang digunakan, menggunakan bahasa yang baik dan benar serta komunikatif sesuai dengan taraf perkembangan siswa (Rustam, 2014)

Berdasarkan uraian di atas maka proses pembelajaran sebaiknya berorientasi pada peserta didik, dan bukan berorientasi pada pendidik. Dalam proses pembelajaran diupayakan dapat menciptakan lingkungan belajar yang 
memungkinkan siswa untuk aktif dan responsif sehingga memperoleh pemahaman yang cepat dan menyeluruh tentang konsep pelajaran kejuruan yang akan digunakan sebagai bekal untuk melaksanakan tugas kompetensi kimia analisis.

Banyak siswa yang merasa kesulitan dalam memahami materi analisis gravimetri. Hal ini ditunjukkan dari hasil prestasi belajar mereka masih di bawah nilai Kriteria Ketuntasan Minimal (KKM) yang ditetapkan. Pada program keahlian kimia analisis, materi tersebut sangat penting karena merupakan materi kejuruan yang harus dikuasai oleh peserta didik. Kompetensi dasar pada pelajaran analisis gravimetri kelas XI SMK meliputi analisis gravimetri metode penguapan dan analisis gravimetri metode pengendapan.

Kenyataan di lapangan siswa kurang aktif, kurang responsif dalam mengikuti kegiatan pelajaran, demikian pula pendidik kurang kreatif dengan metode ceramah yang monoton dalam pemberian materi pelajaran, di sisi lain idealnya bahwa siswa sebagai pusat belajar hendaknya aktif dan antusias, demikian pula pada materi pembelajaran dikemas menarik dan menyenangkan sehingga tidak membosankan siswa. Dengan demikian siswa menjadi lebih mudah dan cepat dalam memahami materi analisis gravimetri. Berdasarkan kenyataan tersebut maka perlu adanya solusi dengan cara melakukan tindakan untuk meningkatkan pemahaman siswa pada materi analisis gravimetri dengan menggunakan model pembelajaran yang menarik yaitu dengan Project Based Learning. Model Project Based Learning ini mempunyai kelebihan yaitu siswa terlibat aktif dalam penentuan proyek, perancangan langkahlangkah penyelesaian, penyusunan jadwal pelaksanaan proyek, penyelesaian proyek dengan fasilitas dan monitoring guru, penyampaian hasil kegiatan dan presentasi/publika, evaluasi proses dan hasil proyek.

Beberapa penelitian tentang model pembelajaran dengan pendekatan saintifik menunjukkan hasil yang cukup menggembirakan. Di antaranya adalah penelitian Yasmin Patiawati (2017) dengan menerapkan pendekatan saintifik dalam meningkatkan Kemampuan Penalaran Adaptif Siswa SMP. Penelitian juga sudah dilakukan Zakiyah Ismuwardani (2019) yaitu Implementation of Project Based Learning Model to Increased Creativity and Self-Reliance of Students on Poetry Writing Skill.

Latar belakang permasalahan yang dapat diidentifikasi adalah sebagai berikut: 1) Siswa kurang semangat dalam belajar dan pasif, 2) Siswa kesulitan dalam menguasai kompetensi analisis gravimetri karena pendidik lebih banyak melaksanakan proses pembelajaran dengan ceramah, diskusi, dan tanya jawab, 3) Kreativitas dan motivasi belajar siswa rendah, karena pendidik kurang melibatkan siswa dalam aktivitas pembelajaran, 4) Hasil belajar kompetensi analisis gravimetri yang dicapai siswa masih rendah, persentase nilai hasil belajar yang di bawah ketuntasan minimal lebih dari lima puluh persen, 5) Pembelajaran kurang menarik bagi peserta didik, monoton, dan kurang variatif, 6) Media pembelajaran kurang memotivasi dan kurang memberi kesempatan pada siswa untuk belajar dan mengembangkan kreativitasnya.

Berdasarkan latar belakang dan pembatasan masalah di atas permasalahan dalam penelitian ini dirumuskan sebagai berikut: 1) Bagaimanakah penerapan project based learning dengan pendekatan saintifik dalam meningkatkan hasil belajar analisis gravimetri pada siswa kelas XI kimia analisis SMK Negeri 2 Depok Tahun 2018/2019 ?, 2) Bagaimanakah pengaruh project based learning dengan pendekatan saintifik terhadap hasil belajar analisis gravimetri kelas XI kimia analisis SMK Negeri 2 Depok Tahun 2018/2019?

Berdasarkan rumusan masalah tersebut di atas, maka tujuan penelitian tindakan kelas ini adalah sebagai berikut: 1) Menerapkan project based learning dengan pendekatan saintifik dalam meningkatkan hasil belajar analisis gravimetri pada siswa kelas XI kimia analisis SMK Negeri 2 Depok Tahun 2018/2019,2) Mengetahui pengaruh project based learning dengan pendekatan saintifik terhadap hasil belajar analisis gravimetri kelas XI kimia analisis SMK Negeri 2 Depok Tahun 2018/2019.

\section{Metode Penelitian}

\section{Jenis Penelitian}

Penelitian ini merupakan penelitian tindakan kelas atau classroom action research. Penelitian ini bersifat deskriptif dan didukung dengan data hasil penelitian. Penelitian berdasarkan data hasil penelitian dan dasar teori yang sudah ada untuk menarik kesimpulan.

\section{Waktu dan Tempat Penelitian}

Penelitian dilaksanakan di SMK Negeri 2 Depok, Sleman Yogyakarta pada bulan Januari 2019 sampai April 2019. Penelitian dilakukan pada saat proses pembelajaran analisis gravimetri yang bertempat di laboratorium analisis SMK Negeri 2 Depok, Sleman, Yogyakarta.

\section{Sasaran Penelitian}

Sasaran penelitian adalah untuk meningkatkan hasil belajar analisis gravimetri 
kususnya kompetensi analisis gravimetri metode penguapan dan analisis gravimetri metode pengendapan pada siswa kelas XI program keahlian Kimia Analisis tahun 2018/2019 dengan menggunakan project based learning.

\section{Subyek Penelitian}

Subyek penelitian adalah siswa Kelas XI Kimia Analisis SMK Negeri 2 Depok Sleman berjumlah 32 orang. Siswa kelas XI kimia analisis terdiri dari 29 siswa perempuan dan 3 siswa lakilaki.

\section{Prosedur Penelitian}

Penelitian dilakukan dalam 4 siklus yaitu pra-siklus, siklus 1 , siklus 2 , dan siklus 3 . Desain penelitian tindakan kelas sesuai dengan yang diungkapkan oleh Yuliawati (2012) terdiri dari 3 siklus dimana 1 siklus terdiri dari beberapa langkah tindakan. Pelaksanaan penelitian tindakan kelas dilakukan dalam satu siklus terdiri dari beberapa tatap muka. Setiap tatap muka terdiri dari perencanaan, tindakan, observasi dan refleksi.

\section{Data, Instrumen, dan Teknik Pengumpulan Data}

Instrumen penelitian yang digunakan adalah rencana pelaksanaan pembelajaran (RPP) yang telah disusun oleh peneliti dengan project based learning dengan pendekatan saintifik yang telah direncanakan terlebih dahulu di baca dan di nilai oleh kolaborator, instrumen penilaian kinerja pendidik dalam proses pembelajaran meliputi penguasaan materi, pengelolaan kelas, pengaturan alokasi waktu, ketrampilan dalam penggunaan alat praktik, intonasi suara pada saat menerangkan materi, Instrumen penilaian hasil belajar untuk mengetahui hasil belajar siswa pra siklus, siklus 1 , siklus 2, dan siklus 3 yang dibuat dalam bentuk soal pilihan ganda yang berjumlah 20 butir soal dengan skor 5 jika siswa menjawab dengan benar dan nilai 0 jika siswa menjawab salah. Nilai evaluasi belajar adalah jumlah skor yang diperoleh. Soal pilihan ganda pada pra siklus berisi 20 indikator yang harus dicapai pada materi analisis gravimetri metode penguapan, soal pilihan ganda pada siklus 1 berisi 20 indikator yang harus dicapai pada materi analisis gravimetri metode penguapan, soal pilihan ganda pada siklus 2 berisi 20 indikator yang harus dicapai pada materi analisis gravimetri metode pengendapan, soal pilihan ganda pada siklus 3 berisi 20 indikator yang harus dicapai pada materi analisis gravimetri metode pengendapan.

Instrumen penilaian project based learning dengan pendekatan saintifik digunakan untuk menilai aktivitas proses pembelajaran dengan menggunakan model project based learning. Skor penilaian yaitu jika semua kriteria terpenuhi maka diberi skor 3, jika salah satu kriteria tidak terpenuhi maka diberi skor 2, jika semua kriteria tidak terpenuhi maka diberi nilai 0 . Nilai hasil project based learning dihitung dengan cara jumlah skor dikalikan 10 kemudian dibagi 3 . Penilaian project based learning terdiri dari 10 kriteria yaitu: mengamati, merumuskan masalah, merumuskan hipotesis, mengumpulkan data, menganalisis data, menarik kesimpulan, kreativitas project based learning, penggunaan IT, proses presentasi, waktu penyelesaian tugas.

Metode pengumpulan data yang digunakan meliputi observasi aktivitas pendidik dan siswa selama proses pembelajaran berlangsung, instrumen aktivitas peserta didik, instrumen tes tertulis, Instrumen penilaian praktik, foto kegiatan selama proses pembelajaran, penilaian project based learning.

Perencanaan tindakan siklus 1 yang dilakukan adalah membuat RPP dengan menggunakan project based learning, menyiapkan lembar kerja siswa yang berisi tugas project based learning, menyiapkan lembar instrumen penilaian aktivitas siswa selama pembelajaran, menyusun instrumen evaluasi hasil belajar siswa berupa soal pilihan ganda dan jawabannya, menyiapkan lembar observasi pendidik yang akan digunakan oleh kolaborator dalam mengamati proses pembelajaran, menyusun instrumen penilaian pendidik dalam pembuatan RPP, menyiapkan penilaian kinerja, baik afektif maupun psikomotorik, pelaksanaan atau tindakan.

Pelaksanaan tindakan dilakukan untuk mengatasi permasalahan hasil belajar siswa yang rendah dengan melaksanakan proses pembelajaran yang dilakukan oleh peneliti dan dilakukan pengamatan oleh kolaborator atas segala yang terjadi pada saat pelaksanaan tindakan. Pengamatan dicatat dalam lembar observasi yang disusun sesuai permasalahan yang diangkat dan kemungkinan-kemungkinan yang muncul saat pelaksanaan tindakan pada proses pembelajaran.

Kolaborator melakukan pengamatan selama proses belajar mengajar berlangsung dengan cara mengisi instrumen observasi aktivitas peserta didik. Kegiatan yang dilakukan oleh kolaborator selama proses pembelajaran adalah mengisi lembar observasi aktivitas peserta didik, observasi kegiatan pendidik, penilaian project based learning, penilaian presentasi hasil project based learning. Berdasarkan hasil refleksi pada siklus 1 maka pendidik mempunyai rencana perbaikan pada pembelajaran siklus 2 dengan melakukan perencanaan yang lebih baik. Hasil refleksi pada siklus 2 sebagai dasar untuk rencana perbaikan 
pada pembelajaran siklus 3 dengan melakukan perencanaan yang lebih baik.

\section{Teknik Analisis Data}

Analisis yang digunakan dalam penelitian ini adalah memanfaatkan analisis deskriptif dari proses dan hasil belajar. Hasil analisis pada siklus 1 direfleksikan ke siklus 2, kemudian hasil analisis siklus 2 direfleksikan ke siklus 3 . Refleksi yang dilakukan sesuai dengan perencanaan yang dilakukan. Data dari penilaian hasil belajar dianalisis dengan analisis butir soal. Nilai evaluasi belajar yaitu jumlah skor. Setelah itu dibandingkan dengan KKM yang telah ditetapkan oleh sekolah. Hasilnya adalah persentase siswa yang masih di bawah KKM dan persentase siswa yang sudah di atas KKM.

Pelaksanaan proses pembelajaran dinyatakan efektif apabila ada kesesuaian antara RPP dan pelaksanaan pembelajaran di depan kelas, diikuti dengan peningkatan aktivitas dan hasil belajar. Adanya peningkatan aktivitas pada kegiatan pra siklus, siklus 1, siklus 2, dan siklus 3 .

Kriteria keberhasilan dari penelitian ini yaitu adanya peningkatan jumlah siswa yang mencapai nilai KKM pada setiap siklus, daya serap yang dicapai oleh siswa $\geq 80 \%$, peningkatan aktivitas belajar siswa pada setiap siklus.

\section{Hasil Penelitian dan Pembahasan}

Penelitian yang dilakukan terdiri dari 3 siklus dimana 1 siklus terdiri dari beberapa langkah tindakan. Hal ini sesuai yang diungkapkan oleh Yuliawati (2002). Hasil analisis hasil belajar pada siklus 1 sebagai dasar untuk mengambil tindakan pada siklus ke 2. Hasil analisis hasil belajar pada siklus 2 sebagai dasar untuk mengambil tindakan pada siklus 3 .

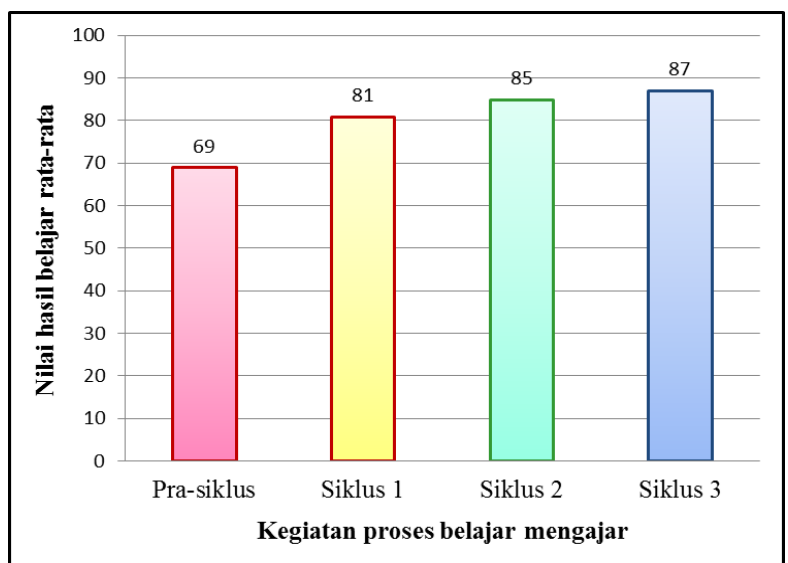

Gambar 1. Grafik hasil belajar rata-rata pada pra siklus, siklus 1, siklus 2, dan siklus 3
Hasil belajar siswa diperoleh dari hasil evaluasi secara tertulis yaitu jawaban soal pilihan ganda. Grafik hasil belajar rata-rata pada pra siklus, siklus 1, siklus 2, siklus 3 disajikan pada Gambar 1. Grafik tersebut menunjukkan kenaikan hasil belajar yang signifikan. Rendahnya nilai evaluasi belajar siswa pada pra siklus disebabkan siswa kurang fokus dan kurang bersemangat pada pelajaran sehingga hasil evaluasi tertulis rendah. Kegiatan siklus 1 menggunakan project based learning mengharuskan siswa untuk aktif dalam pembelajaran. Pada model pembelajaran ini siswa harus aktif dalam mencari materi pembelajaran, mengerjakan proyek, mempresentasikan proyek sehingga materi yang di dapat tersebut melekat di ingatan peserta didik. Dengan project based learning maka siswa kreatif dalam mencari materi, melaksanakan eksperimen, suasana pembelajaran menjadi menyenangkan dan materi mudah masuk ke dalam memori peserta didik.

Project based learning merupakan salah satu model pembelajaran yang prosesnya kreatif dan inspiratif. Hal ini sesuai yang diungkapkan oleh Hartono (2013) bahwa mengajar merupakan proses yang inspiratif. Mengajar yang menginspirasi siswa adalah menumbuhkan kreativitas berfikir dan tidak bergantung harus belajar di dalam kelas. Belajar yang inspiratif mampu memacu semangat siswa untuk terus mengembangkan potensinya.

Hal tersebut juga sesuai dengan yang dikemukakan oleh Rustam (2014) bahwa pelaksanaan proses pembelajaran untuk mencapai kompetensi dasar yang dilakukan secara interaktif, menantang, memotivasi siswa untuk berpartisipasi aktif, memberikan prakarsa, kreativitas, kemandirian sesuai bakat, minat, dan perkembangan fisik serta psikologis peserta didik. Kegiatan inti pada pembelajaran tersebut sudah mencakup komponen dalam mengaktifkan peserta didik.

Pada siklus 1 siswa lebih menguasai materi sehingga hasil evaluasi tertulis meningkat. Pada siklus 2 dan 3 siswa sudah terbiasa dengan project based learning sehingga materi lebih mudah dikuasai dan hasil belajar menjadi meningkat. Hal tersebut sesuai dengan yang dikemukakan oleh Rustam (2014) bahwa penilaian dilakukan Pendidik terhadap hasil pembelajaran untuk mengukur tingkat pencapaian kompetensi peserta didik, digunakan sebagai bahan penyusunan laporan kemajuan hasil belajar, dan memperbaiki proses pembelajaran. Siklus 2 berfungsi untuk memperbaiki proses pembelajaran yang telah dilakukan pada siklus 1. Sehingga hasil belajar rata-rata pada siklus 2 lebih meningkat. Siklus 3 berfungsi untuk memperbaiki proses pembelajaran 
yang telah dilakukan pada siklus 2. Sehingga hasil belajar rata-rata pada siklus 3 lebih meningkat.

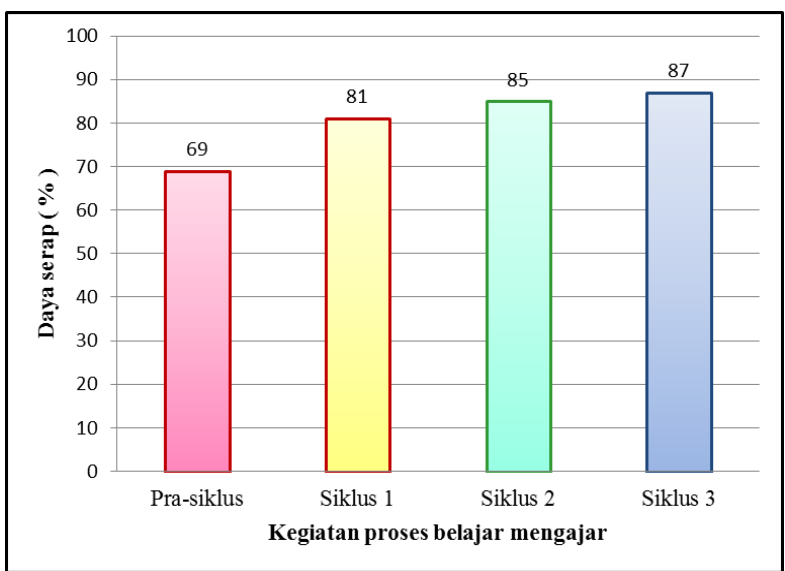

Gambar 2. Grafik daya serap siswa pra siklus, siklus 1 , siklus 2 , dan siklus 3

Grafik daya serap siswa pada pra siklus, siklus 1, siklus 2, siklus 3 disajikan pada Gambar 2. Grafik tersebut menunjukkan kenaikan daya serap yang signifikan. Rendahnya daya serap siswa pada pra siklus disebabkan siswa kurang fokus dan kurang bersemangat pada pelajaran sehingga daya serap pra siklus rendah. Kegiatan siklus 1 menggunakan project based learning mengharuskan siswa untuk aktif, kreatif dan inovatif dalam pembelajaran. Pada model pembelajaran ini siswa harus aktif dalam mencari materi dan melaksanakan eksperimen sehingga materi yang di dapat tersebut melekat di ingatan siswa. Siswa pada siklus 1 lebih menguasai materi sehingga daya serap meningkat. Pada siklus 2 siswa sudah terbiasa dengan project based learning sehingga materi lebih mudah dikuasai dan daya serap menjadi meningkat. Pada siklus 3 siswa sudah terbiasa dengan project based learning sehingga materi lebih mudah dikuasai dan daya serap menjadi meningkat.

Hal ini sesuai dengan yang diungkapkan oleh Muliawan (2016) bahwa suatu pengetahuan akan tertanam secara mendalam pada siswa jika pembelajaran yang melibatkan hampir semua indera peserta didik. Dengan menggunakan project based learning maka pengetahuan lebih tertanam secara mendalam pada siswa dibandingkan model lain karena hampir semua indera dalam siswa terlibat dalam proses project based learning.

Grafik siswa yang memenuhi KKM pada pra siklus, siklus 1 , siklus 2 , siklus 3 disajikan pada Gambar 3. Grafik tersebut menunjukkan kenaikan siswa yang memenuhi KKM secara signifikan. Rendahnya siswa yang memenuhi KKM pada pra siklus disebabkan siswa kurang fokus dan kurang bersemangat pada pelajaran. Kegiatan siklus 1 menggunakan project based learning mengharuskan siswa untuk aktif, kreatif dan inovatif dalam pembelajaran. Pada project based learning ini siswa harus aktif dalam melaksanakan eksperimen sehingga materi yang di dapat tersebut melekat di ingatan peserta didik. Pada siklus 1 siswa lebih menguasai materi sehingga hasil evaluasi tertulis meningkat dan siswa yang memenuhi KKM juga meningkat. Pada siklus 2 siswa sudah terbiasa dengan project based learning sehingga materi lebih mudah dikuasai dan jumlah siswa yang memenuhi KKM menjadi meningkat. Pada siklus 3 siswa sudah terbiasa dengan project based learning sehingga materi lebih mudah dikuasai dan jumlah siswa yang memenuhi KKM menjadi meningkat.

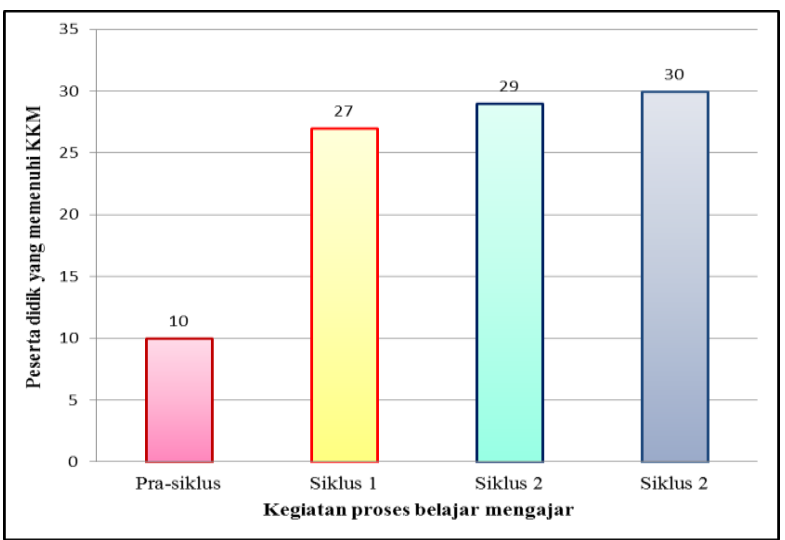

Gambar 3. Grafik siswa yang memenuhi KKM pada pra siklus, siklus 1 , siklus 2 , dan siklus 3

Kenyataan tersebut sesuai dengan pernyataan yang diungkapkan oleh Asmani (2013) bahwa proses pembelajaran harus aktif, kreatif, efektif dan menyenangkan. Pendidik harus pandai dalam memilih media pembelajaran yang bisa mengaktifkan peserta didik, kreatif dan menyenangkan. Project based learning merupakan model yang membuat siswa aktif, kreatif dan menyenangkan.

Hasil tersebut sesuai dengan yang diungkapkan oleh Supriyadi (2011) bahwa siswa yang belajar aktif dapat menghidupkan dan melatih memori siswa bekerja secara optimal. Cara mengaktifkan siswa dengan cara memberikan pengalaman belajar bermakna yang bermanfaat bagi kehidupan peserta didik. Pengalaman bermakna tersebut bisa diperoleh dengan menggunakan project based learning.

Hal ini sesuai dengan yang diungkapkan oleh Muliawan (2016) bahwa proses pembelajaran harus efektif dan efisien. Pendidik harus menggunakan berbagai media pembelajaran yang dapat membantu peserta didik. Model pembelajaran yang dipilih oleh pendidik yaitu project based learning merupakan model 
pembelajaran yang efektif, kreatif, dan menyenangkan.

Project based learning meningkatkan aktivitas siswa karena pada model pembelajaran ini banyak aktivitas siswa yang dilakukan di dalam kelas. Aktivitas siswa yang dilakukan pada project based learning tersebut adalah siswa secara berkelompok aktif dalam penentuan proyek, perancangan langkah-langkah penyelesaian, penyusunan jadwal pelaksanaan proyek, penyelesaian proyek dengan fasilitas dan monitoring guru, penyampaian hasil kegiatan dan presentasi/publika, evaluasi proses dan hasil proyek, mempresentasikan hasil proyek di depan kelas dan kelompok lain menanggapi diskusi, siswa mengerjakan soal evaluasi tertulis.

Sesuai dengan yang diungkapkan oleh Uno (2012) aktivitas siswa dalam belajar dapat dibangun dengan cara siswa menemukan caranya sendiri untuk memperdalam pengetahuan yang dipelajari. Pembelajaran yang inovatif merupakan strategi pembelajaran yang mendorong aktivitas belajar.

Project based learning merupakan salah satu model pembelajaran kreatif yang bisa dilaksanakan oleh pendidik pada proses belajar belajar mengajar. Hal ini sesuai dengan yang diungkapkan oleh faizi (2013) bahwa pendidik dapat kreatif mencobakan dan mengembangkan model pembelajaran sendiri yang khas, sesuai dengan kondisi yang nyata di tempat kerja masing-masing. Sehingga akan muncul model pembelajaran versi baru yang memperkaya khasanah pembelajaran yang telah ada.

\section{Simpulan dan Saran}

\section{Simpulan}

Berdasarkan hasil penelitian tindakan kelas yang telah dilaksanakan yaitu penerapan model project based learning dengan pendekatan saintifik dalam meningkatkan hasil belajar analisis gravimetri maka dapat ditarik kesimpulan sebagai berikut: (1) penerapan model project based learning dengan pendekatan saintifik meningkatkan hasil belajar analisis gravimetri siswa kelas XI program keahlian kimia analisis tahun 2018/2019, (2) Project based learning dengan pendekatan saintifik berpengaruh terhadap hasil belajar analisis gravimetri kelas XI kimia analisis SMK Negeri 2 Depok Tahun 2018/2019

\section{Saran}

Berdasarkan hasil penelitian tindakan kelas mengenai penerapan model project based learning dengan pendekatan saintifik meningkatkan hasil belajar analisis gravimetri siswa kelas XI program keahlian kimia analisis tahun 2018/2019 maka dapat disampaikan saran-saran sebagai berikut:

1. Bagi pendidik disarankan untuk melakukan penelitian dengan model pembelajaran lainnya. Hal ini dimaksudkan agar pendidik lain dapat mengkaji teori-teori yang berkaitan dengan penggunaan model pembelajaran sebagai salah satu alternatif untuk meningkatkan hasil belajar siswa yang belum terdapat dalam penelitian ini. Bagi pendidik lain maka hasil penelitian ini bisa dijadikan sebagai acuan untuk dikembangkan menjadi penelitian yang lebih menarik.

2. Bagi siswa disarankan untuk dapat belajar secara aktif dengan menerapkan model project based learning dengan pendekatan saintifik untuk pembelajaran pada kompetensi selanjutnya.

\section{Daftar Pustaka}

Aqib Zainal. (2013). Model-model, Media, dan Strategi Pembelajaran Kontekstual. Bandung: Yrama Widya.

Asmani Jamal Ma'mur. (2013). 7 Tips Aplikasi PAKEM (Pembelajaran Aktif, Kreatif, Efektif, dan Menyenangkan). Yogyakarta: DIVA Press.

Faizi Mastur. (2013). Ragam Mengajarkan Eksakta pada Murid. Yogyakarta: Diva Press

Hartono R. (2013). Ragam Model Mengajar yang Mudah Diterima Murid. Yogyakarta : Diva Press.

Hosnan. (2014). Pendekatan Saintifik dan KOntekstual dalam Pembelajaran Abad 21. Bogor: Ghalia Indonesia

Huda Miftahul. 2013. Model-model Pengajaran dan Pembelajaran: Isu-isu Metodis dan Paradigmatis. Yogyakarta: Pustaka Pelajar.

Kemendikbud. (2014). Salinan Lampiran Permendikbud No. 103 Tahun 2014. Pedoman Pelaksanaan Pembelajaran. Jakarta: Kemendikbud.

Knoll, M. (2002). The Project Method: Its Vocational Education Origin and International Development. Journal of Industrial Teacher Education, 34(3). Diakses tanggal 6 Juni 2019 dari http: 
//scholar.lib.vt.edu/ejournals/JITE/v34n3/Kn oll.html.

Kosasih E. (2014). Strategi Belajar dan Pembelajaran Implementasi Kurikulum 2013. Bandung: Yrama Widya

Muliawan Jasa Ungguh. (2016). 45 Model Pembelajaran Spektakuler. Yogyakarta: ArRuzz Media

Rustam. (2014). Model-model Pembelajaran: Mengembangkan Profesionalisme Pendidik. Jakarta: Raja Grafindo Persada.

Sanjaya Wina. (2010). Strategi Pembelajaran Berorientasi Standar Proses Pendidikan. Bandung: Kencana.

Shoimin Aris. (2014). 68 Model Pembelajaran Inovatif dalam Kurikulum 2013. Yogyakarta: Ar-russ Media

Supriyadi. (2011). Strategi Belajar dan Mengajar. Yogyakarta: Cakrawala Ilmu.

Thomas, J.W. (2000). A Review of Research on Project Based Learning. Diakses tanggal 6 Juni 2019 dari http://www.autodesk.com/foundation

Trianto. (2011). Mendesain Model Pembelaja-ran Inovatif-Progresif, Konsep, Landasan, dan Implementasinya pada Kurikulum Tingkat Satuan Pendidikan. Jakarta: Kencana Prenada Media Group.

Uno Hamzah B. (2012). Belajar dengan Pendekatan Pembelajaran Aktiv Inovatif Lingkungan Kreatif Efektif Menarik. Jakarta: Bumi Aksara.

Waras Kamdi. (2010). Implementasi Project-Based Learning di Sekolah Menengah Kejuruan. Jurnal Pendidikan Dan Pembelajaran, Volume 17, Nomor 1, April 2010.

Yasmin Patiawati. (2017). Penerapan Model Problem Based Learning dengan Pendekatan Saintifik untuk Meningkatkan Kemampuan Penalaran Adaptif Siswa SMP. Jurnal Pendhartidikan dan Pembelajaran Untan Vol 6 No 7 Juli 2017
Yuliawati Fitri. (2012). Penelitian Tindakan Kelas untuk Tenaga Pendidik Profesional. Yogyakarta: Pedagogia.

Zakiyah Ismuwardani. (2019). Implementation of Project Based Learning Model to Increased Creativity and Self-Reliance of Students on Poetry Writing Skills. Journal of Primary Education UNNES. Vol 8 No 1 Tahun 2019 : $51-58$ 